\title{
Alcohol Use and its Consequences Among Canadian University Students
}

\author{
ANUPPA CALEEKAL-JOHN and MICHAEL S. GOODSTADT*
}

\begin{abstract}
Alcohol use and abuse in Canadian society has been the focus of attention for many years. Studies have tended, however, to be concerned with either general populations (e.g. Single et al., 1981; Smart and Adlaf, 1982), or with those of school age (e.g. Smart et al., 1981). Little consideration has been given to the role and impact of alcohol in the lives of an important subgroup of Canadian society, namely, university and college students. Although small, this subpopulation represents a significant investment of society's educational and financial resources, and is also considered to be one of society's important future assets. The present review will examine the available data concerning college students' alcohol use; where appropriate comparisons will be made with United States' data. It is significant at the outset, to note that all Canadian data refer only to university students; no relevant information has been uncovered for students enrolled in colleges of applied arts and technology.
\end{abstract}

\section{PREVALENCE, FREQUENCY AND VOLUME OF ALCOHOL USE AMONG UNIVERSITY STUDENTS}

Table 1 summarizes alcohol consumption data from the few available studies of alcohol use among Canadian university students. Comparison between studies is problematic, since the data represents responses to different questions, presented to samples obtained by varying procedures, at different times and locations. The evidence suggests, however, that the overwhelming majority of students (approximately $90 \%$ ) now report drinking alcohol. Equal proportions (i.e. approximately one-third) of drinkers drink less than once a week, once a week, and more than once a week; a small group (perhaps 6\%) report drinking every day. Data regarding volume of alcohol consumed per drinking occasion are less consistent: a conservative estimate indicates that more than $13 \%$ of drinkers consume more than 5 drinks per occasion, while one survey (Bacchus, 1982) suggests that this figure may be as high as $34 \%$.

In examining the degree to which Canadian university students differ from other segments of the population, it appears that: (i) the prevalence and frequency of alcohol use is greater among Canadian university students than among

* Education Research Section, Addiction Research Foundation, Toronto, Canada. 
TABLE 1

Summary of Surveys of Alcohol Consumption Among Canadian University Students

\begin{tabular}{|c|c|c|c|c|c|c|c|c|c|}
\hline \multirow{2}{*}{ Author (s) } & \multirow{2}{*}{$\begin{array}{l}\text { Year of } \\
\text { Publica- } \\
\text { tion }\end{array}$} & \multicolumn{5}{|c|}{ Sample Characteristics } & \multicolumn{3}{|c|}{ Reported Alcohol Use } \\
\hline & & Location & $\begin{array}{l}\text { Popula- } \\
\text { tion }\end{array}$ & Sampling & Year & $\begin{array}{c}\text { Size } \\
\text { (Response } \\
\text { Rate })\end{array}$ & Prevalence & Frequency & Volume \\
\hline $\begin{array}{l}\text { Information } \\
\text { Canada }\end{array}$ & 1973 & Canada & $\begin{array}{l}\text { University } \\
\text { Students }\end{array}$ & $?$ & 1970 & & $83 \%:$ "ever drank" & $\begin{aligned} 59 \%: & \text { >once in previous } \\
& 6 \text { months" }\end{aligned}$ & $\cdots$ \\
\hline Doucet et al. & 1977 & $\begin{array}{l}\text { Nova } \\
\text { Scotia }\end{array}$ & $\begin{array}{l}\text { Under- } \\
\text { grads. }\end{array}$ & $\begin{array}{l}\text { "Represen- } \\
\text { tative" }\end{array}$ & 1977 & $\begin{array}{c}917 \\
(92:)\end{array}$ & $\begin{array}{c}92 \%: \text { "consume alcoholic } \\
\text { beverages" }\end{array}$ & -- & $\begin{array}{l}\text { Average Weekly Consump- } \\
\text { tion (Anong drinkers) } \\
7 \%: \leqslant 1.0 .02 . \text { abs:alc. } \\
25 \%: 1.1-3.0 \mathrm{oz} . \\
30 \%: 3.1-6.5 \mathrm{oz} . \\
23 \%: 6.6-11.1 \mathrm{oz} . \\
16 \%: \text { \$11.1 oz. }\end{array}$ \\
\hline $\begin{array}{l}\text { Kerusedy \& } \\
\text { Raudoja }\end{array}$ & 1977 & Guelph & $\begin{array}{l}\text { Under- } \\
\text { grads. }\end{array}$ & Random? & 1976 & $\begin{array}{c}970 \\
(81 \%)\end{array}$ & $\begin{array}{l}90 \%: \text { "presently use } \ldots \\
\text { more than } 6 \text { times } \\
\text { a year" }\end{array}$ & $\begin{array}{l}\text { (Among drinkers) } \\
248: \text { once or twice/month } \\
328: \text { once/week } \\
368: 2-3 \text { times/week } \\
7 \%: \text { daily }\end{array}$ & $\begin{array}{l}\text { (Nmong drinkers) } \\
388: 1-2 \text { drinks per occ. } \\
49 \%: 3-5 \text { drinks per occ. } \\
13: \text { : } 6-10 \text { drinks per oce }\end{array}$ \\
\hline McMurray & 1980 & Guelph & $\begin{array}{l}\text { Under- } \\
\text { grads. }\end{array}$ & Random & 1980 & $\begin{array}{l}164 \\
\{968\}\end{array}$ & $88 \%$ : currently drinkers & $\begin{array}{l}\text { (Among drinkers) } \\
299: \text { <once/week } \\
399: \text { once/week } \leftarrow \\
27 \%: \text { three times/week } \\
\text { 6\%: daily }\end{array}$ & $\begin{array}{l}\text { (Among drinkers) } \\
-(\overline{\mathrm{i}}-\overline{\mathrm{e}}, 29 \%: 1-2 \text { drinks; } \\
+10 \%: 4-6 \mathrm{drinks}) \\
-(\mathrm{i}, \mathrm{e}, 21 \%: 1-2 \text { drinks; } \\
+6 \%: 4-6 \text { drinks) } \\
\text { (i.e. } 5 \% 1-2 \text { drinks; } \\
+1 \%: \geqslant 10 \text { drinks) }\end{array}$ \\
\hline $\begin{array}{l}\text { Cal eekal- } \\
\text { John }\end{array}$ & $\begin{array}{l}\text { (in } \\
\text { press) }\end{array}$ & Guelph & $\begin{array}{l}\text { Inder- } \\
\text { grads. }\end{array}$ & $\begin{array}{l}\text { Course } \\
\text { partici- } \\
\text { pants }\end{array}$ & 1981 & 18 & $94 \%$ : ever consumed & $\begin{array}{l}\text { (Among drinkers) } \\
128: \text { sonce/month } \\
30 \%: 2-3 \text { times/month } \\
298: \text { gnce/week } \\
30 \%: 3-3 \text { times/week }\end{array}$ & $\begin{array}{l}\text { (Among drinkers) } \\
308: \leqslant 6 \text { drinks/month } \\
34:: 8-16 \text { drinks/month } \\
36 \%:>16 \text { drinks/month }\end{array}$ \\
\hline Bacchus & 1982 & $\begin{array}{l}\text { Wilfrid } \\
\text { Laurier }\end{array}$ & \begin{tabular}{|c} 
Inder- \\
grads. \\
(383) \\
Grads. \\
\& Staff \\
$(20)$ \\
\end{tabular} & $\begin{array}{l}\text { Availa- } \\
\text { bility }\end{array}$ & 1981 & $\begin{array}{l}403 \\
(?)\end{array}$ & $\begin{array}{l}\text { 89: : currently drink } \\
9 \% \text { previously but not } \\
\text { now } \\
2 \%: \text { have never }\end{array}$ & $\begin{array}{l}\text { (Among "ever" drinkers) } \\
9 \%: \text { sonce/month } \\
18 \%: \text { twice/month } \\
32 \%: \text { once/week } \\
277^{\circ}: \text { twice/week } \\
15 \%: \text { three times/week }\end{array}$ & $\begin{array}{l}\text { (Anong "ever" drinkers) } \\
10:: \leqslant 1 \text { drink per occ. } \\
14 \%: 2 \text { drinks per occ. } \\
22 \%: 3 \text { drinks per occ. } \\
20 \%: 4 \text { drinks per occ. } \\
34 \%: \geq 5 \text { drinks per occ. }\end{array}$ \\
\hline Mcleod & 1981 & \begin{tabular}{|l} 
New \\
Brunswick
\end{tabular} & Students & $?$ & 1977 & $\begin{array}{c}500 \\
\text { dr inker }\end{array}$ & $(100 \%)$ & 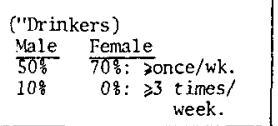 & $\begin{array}{l}\text { ("Trinkers") } \\
\begin{array}{ll}\text { Male } & \text { Female } \\
708 & 505: 3-5 \mathrm{drink} / \mathrm{wk} \\
70 \% & 10 \%: \geqslant 5 \mathrm{drinks} / \mathrm{wk}\end{array}\end{array}$ \\
\hline
\end{tabular}


Canadian adults aged 15 years and over, but no greater than the equivalent agecohort (i.e. 20 - 24 year olds) in the general population (Health and Welfare Canada and Statistics Canada, 1981); (ii) whereas the prevalence of alcohol use for Canadian university students does not appear to differ greatly from that found for Ontario Grade 13 high school students (Smart et al., 1981), the university students' frequency of alcohol use is much greater than that of Grade 13 students (for example, only $24.1 \%$ of Grade 13 students in 1981 reported drinking once a week or more frequently, and less than $1 \%$ drank almost every day). These differences in drinking patterns between Grade 13 and university students may be accounted for, in part, by university students being more likely to have reached the legal minimum age for alcohol consumption.

In contrast to the paucity of Canadian data, many U.S. studies have compared trends in college students' alcohol use. These have all documented the same high rates of alcohol use and, in some cases, alcohol-related problems. Blane and Hewitt (1977), in reviewing 68 college surveys, concluded that drinking among U.S. college students has been rising since 1936 (1936-65: 71.4\%, 1966-70: 84.3\%; 1971-77: 88.5\%); today's students drink more frequently and become intoxicated more often than college students of twenty-five years ago; drinking among college students differ little as compared to non-college youth. Other studies have shown similar trends (e:g. Corder et al., 1974; Kraft, 1977; Hanson, 1977; Kopplin et al., 1977; Dezelsky et al., 1981).

\section{ALCOHOL USE IN RELATION TO THE USE OF OTHER DRUGS}

"Le Dain" Commission (Information Canada, 1973) surveys indicated that alcohol use was more prevalent than the use of any other drug: for example, an average of $83 \%$ had used alcohol compared to estimates of $30-45 \%$ for marijuana. Other comparative Canadian data are unavailable, although the results of surveys of Ontario adults (Smart and Goodstadt, 1976 and 1978; Smart and Adlaf, 1982) show that alcohol use among 18-29 year olds is much more frequent than the use of other drugs (approximately $85 \%$ vs $23 \%$ ). U.S. studies have similarly shown that alcohol is the most extensively used drug, with marijuana coming a distant second (Milman, 1973; Fagerberg and Fagerberg, 1976; Kaplan, 1979; and Dezelsky et al., 1981).

\section{NEGATIVE BEHAVIOURAL CONSEQUENCES RELATED TO ALCOHOL USE}

Doucet et al., (1977), Caleekal-John (in press), Mills and McCarty (1983), have found relationships between increased alcohol consumption and occurrence of negative behavioural consequences. Caleekal-John found similarities between her Canadian data and the U.S. findings of Engs (1977) and Walfish et al., (1981b), all of which employed identical measures: negative consequences included hangovers, vomiting, and drinking and driving; less common, but not inconsequential, were educational and psychosocial consequences. Doucet et al., (1977) found 
that more than $50 \%$ of their sample reported missing classes and being sick due to alcohol consumption. Kennedy and Raudoja (1977) reported that $15 \%$ of students experienced hallucinations due to drinking, 33\% suffered blackouts or memory loss, $9 \%$ had received special medical or psychological treatment for drinking, $13 \%$ of the sample worried about drinking and $39 \%$ said they had lost time from classes because of drinking. Similar reports of alcohol-related problems are to be found in U.S. studies (e.g. Kooi, 1961; Kraft, 1975; Wechsler and McFadden, 1979; Wechsler and Rohman, 1981).

\section{DEMOGRAPHIC CHARACTERISTICS RELATED TO ALCOHOL USE}

\section{Sex and Age}

Male students have been consistently found to drink more frequently and more heavily than female students (Kennedy and Raudoja, 1977; Bacchus, (1982); Doucet et al., 1977). The Canada Health Survey (1978-79) showed that the comparable age group of young males, $20-24$ years of age, constituted the cohort with highest proportion for those drinking more than 13 drinks per week. Similar findings are reported by U.S. studies (Strauss and Bacon, 1953; Engs, 1977; Kaplan, 1979; Wechsler and Rohman, 1981). Blane and Hewitt (1977) concluded, from their extensive review of U.S. studies, that sex seems to be more strongly associated with excessive alcohol use or abuse than with alcohol use per se.

\section{Class (Academic)}

Bacchus (1982) found some evidence that among Wilfrid Laurier students, third and fourth year students were likely to drink more frequently (i.e., two or more times per week), to spend less time drinking (i.e., four or more hours per occasion), but to drink as much (i.e., four or more drinks) per occasion as compared to younger students. Kraft (1975) and Kaplan (1979, for male students only) reported a similar phenomenon in their U.S. studies.

\section{Place of Residence}

Doucet et al., (1977) found that type of student residence was closely associated with prevalence and frequency of drinking: the largest proportion of drinkers (and heavy drinkers) was found among students who lived in on-campus residences or in "other" locations in contrast to those who lived in apartments or at home or who roomed elsewhere. Ingra and Moos (1979), in the United States, found that a cohesive and drinking-oriented college living group was associated with an increase in students' drinking.

\section{ATTITUDES TOWARDS ALCOHOL USE}

The evidence indicates that students, especially drinkers (Doucet et al., 1977), hold pro-alcohol attitudes, including support for the status-quo regarding availability of alcohol on campus (Kennedy and Raudoja, 1977; Doucet et al., 1977), 
a belief that slight intoxication is sometimes helpful, and that moderate amounts of alcohol help social functioning. Students, however, state that they do not feel pressured to drink or to drink more than they should. They express tolerance for non-drinkers (Kennedy and Raudoja, 1977; Bacchus, 1982) and other responsible attitudes towards alcohol use (Bacchus, 1982), although these attitudes are not always in line with their reported behaviour (Caleekal-John, in press).

\section{MOTIVATIONS FOR DRINKING}

A large range of disparate but not mutually exclusive reasons have been found or suggested for students' alcohol consumption and/or abuse. Among these motivations are included:

(i) Drinking as a symbolic act of rejecting authority, or asserting adulthood (Straus and Bacon, 1953);

(ii) Drinking as a means of coping with new freedoms and challenges, stresses, feelings of frustration, powerlessness, feelings of anxiety or depression, feelings of boredom, and personal problems (e.g., Brooks et al., 1981; Ewing, 1977; Grossman, 1965; Hanson, 1974; Higgins and Marlatt, 1975; Kraft, 1971; Orford, 1976; Scheller-Gilkey et al., 1979; Zax and Specter, 1974);

(iii) Drinking for psycho-social reasons, including the enhancement of relaxation, personal confidence, sexual arousal, celebration, and having fun (e.g., Bacchus, 1982; Scheller-Gilkey et al., 1979; Straus and Bacon, 1953; Wechsler and Rohman, 1981).

(iv) Drinking to get high, drunk etc., to escape, for kicks (e.g., Cahalan et al., 1969, Cahalan, 1970; Jung, 1977; Larsen and Abu-Laban, 1968; Riley and Marden, 1947; Riley et al., 1948; Scheller-Gilkey et al., 1979; Wechsler and Rohman, 1981).

The complexity (e.g. Segal et al., 1980) and significance of these reasons and motivations for college drinking require further scrutiny, especially as they relate to (a) problem drinking (e.g., Beckman and Bardsley, 1981) and (b) alcohol intervention programs.

\section{ENVIRONMENTAL INFLUENCE ON DEVELOPMENT OF STUDENT DRINKING PATTERNS}

\section{Home Environment and Family as a Context for Developing Early Drinking}

Kennedy and Raudoja (1977) found that the majority of students were allowed to drink at home before 18 years of age, beginning by 15 years of age on average; $61 \%$ saw their fathers using alcohol excessively. In the U.S., Fontane and Layne (1979) found that college students' drinking was similar to that of their families. Reiskin and Wechsler (1981) found no such relationship between college students' and parents drinking, although students receiving psychiatric help were signifi- 
cantly more likely than the general population of students to report that their parents drank heavily.

\section{High School Environment as a Context for Developing Drinking Patterns in University}

Kennedy and Raudoja (1977) found there was an increase in the amount and frequency of drinking at university in comparison to high school drinking. Evidence cited earlier suggest that, in Ontario, the frequency, but not the prevalence, of use appears to be dramatically greater among university students in comparison to those in Grade 13.

Banks and Smith's (1980) found 26\% of a sample of 90 students reported that their drinking had increased since attending college, while Wechsler and Rohman (1981) and Buckner (1967) found that heavy use of alcohol among college students was strongly associated with students' drinking patterns in high school.

\section{University Environmental Influence in the Development of Drinking Patterns}

Group Influence and Role Modelling: Drinking among college students is a group phenomenon (Fleming, 1976), being influenced especially through friendship patterns (Hanson, 1974; Liccione, 1980), and the approval for the moderate "social drinker" and rejection of the abstainer and heavy users (Trice and Beyer, 1977). Students' drinking patterns may also be influenced by the large number of (not always responsible) alcohol-related advertisements in college newspapers (Walfish et al., 1981a), and by the high level of alcohol use among university faculty (Leung, 1980).

Availability of Alcohol on Campus: The university environment offers pubs for on-campus alcohol consumption, which, through its availability and favourable pricing, encourage on-campus drinking. (Statistics for Ontario indicate an increase from 14 licensed public establishments on university and college campuses in 1974, to 94 such establishments in 1981). Availability is also increased through the special licensing of on-campus events at which alcohol is served - statistics indicate that approximately 200 Special Occasion (liquor) Permits were issued to Ontario Universities and Colleges during the months October - December, 1982.

Role of University Student Service Personnel: Few universities appear to provide support systems to encourage responsible drinking, and for the identification and treatment of students with alcohol-related problems (see Goodstadt and Caleekal-John (in press) for a review of university alcohol education programs). Henggeler et al., (1980) showed that students rated alcohol abuse, smoking and drug abuse as the three most serious mental health problems, whereas the professionals rated career choice, academic difficulties and coping with stress as the most serious. 


\section{UNIVERSITY ENVIRONMENT AND DRINKING PATTERNS AS A CONTEXT FOR DEVELOPING DRINKING PATTERNS IN LATER LIFE}

There are only limited longitudinal data regarding the continuity of problem and non-problem drinking from college years to early adulthood; no such Canadian data have been found. Fillmore's (1974) 20-year follow-up study of college students found that earlier frequency, quantity and problem drinking were predictive of problem drinking in middle age. Donovan et al's., (1981) longitudinal data suggest that males are more likely to develop problem drinking, and are also more likely to continue in this pattern into adulthood. For both males and females, earlier problem drinking was found to be more persistent than more recently developed problems; this suggests that the maturation process might act as an independent variable in influencing the continuity of problem drinking.

\section{IMPLICATIONS}

Evidence that the overwhelming majority of university students drink does not imply that the college population is composed of alcoholics and problem drinkers. The elevated level of consumption and evidence of serious negative consequences of alcohol use, however, is a cause for concern, particularly if drinking patterns established early in life remain constant for a long period of time. This has implications for the potential health and productivity of graduates. As Donovan (1981) remarks, “. . alcohol problems on campus mirror those off campus and deserve equal attention. Indeed, since today's students will be tomorrow's leaders, one might argue a higher priority".

It is not clear to what extent students consider the implications of their alcohol use in terms of disruptions and costs to themselves, their campus, family, friends and their community at large. Intervention is suggested as a necessary preventive step in reducing or avoiding these consequences, both while at university and after leaving the university environment.

Evidence indicates that interventions should not be limited to junior level students. Alcohol education, however, may not be essential for the entire student population; specific subgroups such as males, in their third and fourth years, living in residences may require it more than other subgroups. Although it may be argued that prevention programs at the college level is not worthwhile because drinking attitudes have already been established by the time a person enters college, it can also be argued that the choice of how to drink remains.

The peer-group and faculty role-modelling influences are likely to have a negative effect on responsible alcohol drinking when these forces act in conjunction with institutional policies which facilitate the availability of alcoholic beverages on campus, through the provision of many alternative licensed settings with few time restrictions and below market prices. This calls for institutional commitment in formulating university alcohol policies with respect to both education, and management of pubs and special liquor licences on campus. 
Institutional co-operation is further needed in the provision of student services for those students with alcohol-related problems. These services should include early identification of problems, counselling, education and treatment.

Finally, it is evident that much research is required to identify the extent and nature of alcohol use among Canadian students, to assess the consequences of this use, and to evaluate the impact of alternative strategies, both educational and institutional, designed to prevent or minimize the untoward consequences of alcohol abuse among this important segment of Canadian society.

\section{REFERENCES}

Bacchus Services. Alcohol use, level of knowledge, and attitudes about alcohol among the students of Wilfrid Laurier University, 1981. Waterloo, Ont.: Wilfrid Laurier University, April, 1982.

Banks, E., \& Smith, M.R. Attitudes and background factors related to alcohol use among college students. Psychological Reports, 1980, 46, 571-577.

Beckman, L.J., \& Bardsley, P.E. The perceived determinants and consequences of alcohol consumption among young women heavy drinkers. The International Journal of the Addictions, 1981, 16, 75-88.

Blane, H.T., \& Hewitt, L.E. Alcohol and youth: An analysis of the literature 1960-75. Rockville, Md.: National Institute on Alcohol Abuse and Alcoholism, 1977.

Brooks, M.L., Walfish, S., Stenmark, D.E., \& Canger, J.M. Personality variables in alcohol abuse in college students. Journal of Drug Education, 1981,11, 185-187.

Buckner, D.R. The influence of residence hall alcoholic beverages and study hour regulation on student behavior. Unpublished doctoral dissertation, The American University, 1967 (University Microfilms No. 68-2790).

Cahalan, D. Problem drinking: A national survey. San Francisco: Jossey-Bass, 1970.

Cahalan, D., Cisin, F.H., \& Crossley, H.M. American drinking practices (Monograph No. 6). New Brunswick, N.J.: Rutgers Centre of Alcohol Studies, 1969.

Caleekal-John, A. An interdisciplinary cognitive approach to alcohol education in the university curriculum. Journal of Alcohol and Drug Education, (in press).

Corder, B., Dezelsky, T., \& Toohey, J. An analysis of trends in drug use behaviour at five American universities. Journal of School Health, 1974, 44, 386-389.

Dezelsky, T.L., Toohey, J.V. \& Kish, R. A ten-year analysis of non-medical drug use behaviour at five American universities. Journal of School Health, 1981, 51, 51-55.

Donovan, B.E. Establishing a university alcohol education/prevention program and some principles. Journal of Alcohol and Drug Education, 1981, 27 (1), 62-77.

Donovan, J.E., Jessor, R. \& Jessor, L. Problem drinking from adolescence to young adulthood. (Research Report No. 2). University of Colorado, Institute of Behavioural Science, July, 1981.

Doucet, J.A., Mersereau, T., Gillis, C. \& Arnold, N. Alcohol consuming patterns among undergraduate university students. Antigonish, N.S., 1977. Paper submitted to the Non-Medical Use of Drugs Directorate, Health and Welfare Canada.

Engs, R. Drinking patterns and drinking problems of college students. Journal of Studies on Alcohol, 1977, 38, 2144-2156.

Ewing, J.A. A biopsychological look at drinking and alcoholism. Journal of the American College Health Association, 1977, 25, 204-208. 
Fagerberg, S. \& Fagerberg, K. Student attitudes concerning drug abuse education and prevention. Journal of Drug Education, 1976, 6, 141-152.

Fillmore, K.M. Drinking and problem drinking in early adulthood and middle age: An exploratory 20-year follow-up study. Quarterly Journal of Studies on Alcohol, $1974,35,819-840$.

Fleming, R.J. A survey of drinking behaviour among Montana State University students and the potential for problems with alcohol: Implications for counselling services, alcohol education and student personnel services. Dissertation Abstracts International, 1976, 37: 9A, 5602.

Fontane, P.E. \& Layne, N.R., Jr. The family as a context for developing youth drinking patterns. Journal of Alcohol and Drug Education, 1979, 24 (3), 19-29.

Goodstadt, M.S. \& Callekal-John, A. Alcohol education programs for university students: A review of their effectiveness. International Journal of the Addictions (in press).

Grossman, P.H. Drinking motivation: A cluster analy tic study of three samples. Unpublished doctoral dissertation. University of Colorado, 1965. (University Microfilms No. 66-2793).

Hanson, D.J. Drinking attitudes and behaviors among college students. Journal of Alcohol and Drug Education, 1974, 19 (3), 6-11.

Hanson, D.J. Trends in drinking attitudes and behavior among college students. Journal of Alcohol and Drug Education, 1977, 22 (3), 17-22.

Health and Welfare Canada and Statistics Canada. The Health of Canadians: Report of the Canada Health Survey, 1978-79. 1981.

Henggeler, S.W., Sallis, J.F. \& Cooper, P.F. Comparison of university mental health needs priorities identified by professionals and students. Journal of Counselling Psycho$\log y, 1980,27,217-219$.

Higgins, R. \& Marlatt, G. Fear of interpersonal evaluation as a determinant of alcohol consumption in male social drinkers. Journal of Abnormal Psychology, 1975, 84, 644-651.

Ingra, A. \& Moos, R. Alcohol use among college students: Some competing hypotheses. Journal of Youth and Adolescence, .1979, 8, 393-405.

Information Canada. Final report of The Commission of Inquiry into the Non-medical Use of Drugs. Ottawa, Canada, 1973.

Jung, J. Drinking motives and behaviour in social drinkers. Journal of Studies on Alcohol, 1977, 38, 944-952.

Kaplan, M.S. Patterns of alcoholic beverage use among college students. Journal of Alcohol and Drug Education, 1979, 24 (2), 26-40.

Kennedy, K. \& Raudoja, J. A report on attitudes and use of alcohol at the University of Guelph. Guelph, Ont.: University of Guelph, Department of Student Affairs, March, 1977.

Kooi, R.C. An analysis of drinking practices and problems among undergraduates at a midwestern university. Unpublished Master's thesis, Western Michigan University, 1961.

Kopplin, D.A., Greenfield, T. \& Wong, H.L. Changing patterns of substance use on campus: A four year follow-up study. International Journal of the Addictions, 1977, 12, 73-74.

Kraft, D.P. Report on alcohol task force findings and recommendations. Oct., 1974 to June, 1975. University of Massachusetts, 1975.

Kraft, D.P. Follow-up of a federal effort to encourage campus alcohol abuse prevention programs. Journal of the American College Health Association, 1977, 26, 150-153. 
Kraft, R. Social anxiety models of alcoholism. Perceptual and Motor Skills, 1971, 33, 978-979.

Larsen, D. \& Abu-Laban, B. Norm qualities and deviant drinking behaviour. Social Problems, $1968,15,411-450$.

Leung, P. Alcohol and drug use of faculty in an urban university setting. Journal of Drug Education, 1980,10, 229-232.

Liccione, W.J. The relative influence of significant others in adolescent drinking: An exploratory study. Journal of Alcohol and Drug Education, 1980, 26 (1), 55-62.

McLeod, J.L. The peer alcohol education project. University of New Brunswick, 1981.

McMurray, U. Survey on alcohol use and attitudes. Guelph, Ont.: University of Guelph, Office of the Provost, April, 1980.

Mills, K.C. \& McCarty, D. A data based alcohol abuse prevention program in a university setting. Journal of Alcohol and Drug Education, 1983, 28 (2), 15-27.

Milman, D.H. \& Su, W.J. Patterns of drug usage among university students versus heavy use of marijuana and alcohol by undergraduates. Journal of the American College Health Association, 1973, 21, 181-187.

Orford, J. A study of the personalities of excessive drinkers and their wives using the approaches of Leary and Eysenck. Journal of Consulting and Clinical Psychology, 1976, 44, 534-545.

Reiskin. H. \& Weschler, H. Drinking among college students using a campus mental health center. Journal of Studies on Alcohol, 1981, 42, 716-724.

Riley, J.W., Jr. \& Marden, C.F. The social pattern of alcoholic drinking. Quarterly Journal of Studies on Alcohol, 1947, 8, 265-273.

Riley, J.W., Jr., Marden, C.F. \& Lifshitz, M. The motivational pattern of drinking, based on the verbal responses of a cross-section of users of alcoholic beverages. Quarterly Journal of Studies on Alcohol, 1948, 9, 353-362.

Scheller-Gilkey, G., Gomberg, E.S., \& Clay, M. College students and alcohol: An exploration of observations and opinions. Journal of Alcohol and Drug Education, 1979, 24 (3), 72-76.

Segal, B., Huba, F.J. \& Singer, J.L. Reason for drug and alcohol use by college students. The International Journal of the Addictions, 1980, 15, 489-498.

Single, E., Giesbrecht, N., \& Eakins, B. The alcohol policy debate in Ontario in the postwar era. In E. Single, P. Morgan and J. de Lint (Eds.) Alcohol, Society and the State, Volume 2: The Social History of Control Policy in Seven Countires. Toronto: Addiction Research Foundation, 1981.

Smart, R.G., \& Adlaf, E.M. Trends in alcohol and drug use among Ontario adults: Report of a household survey, 1982. (Substudy No. 1234). Toronto: Addiction Research Foundation, 1982.

Smart, R.G., \& Goodstadt, M.S. Alcohol and drug use among Ontario adults: Report of a household survey, 1976 (Substudy No. 798). Toronto: Addiction Research Foundation, 1976.

Smart, R.G., Goodstadt, M.S., Sheppard, M.A., Chan, G.C., Adlaf, E.M., \& Liban, C.B. Preliminary report of alcohol and other drug use among Ontario students in 1981, and changes since 1977 and 1979. (Substudy No. 1203). Toronto: Addiction Research Foundation, 1981.

Straus, R. \& Bacon, S. Drinking in college, New Haven, Conn.: Yale University Press, 1953.

Trice, H.M. \& Beyer, J.M. A sociological property of drugs: Acceptance of users of alcohol and other drugs among university undergraduates. Journal of Studies on Alcohol, $1977,38,58-74$. 
Walfish, S., Stenmark, D., Wentz, D., Mayers, C. \& Linares, D. Alcohol-related advertisements in college newspaper. International Journal of the Addictions, 1981, 16, 941-945. (a)

Walfish, S., Wentz, D., Benzing, P., Brennan, F. \& Champ, S. Alcohol abuse on a college campus: A needs assessment. Evaluation and Program Planning, 1981, 4, 163 168. (b)

Wechsler, H. \& McFadden, M. Drinking among college students in New England: Extent, social correlates and consequences of alcohol use. Journal of Studies on Alcohol, $1979,40,969-996$.

Wechsler, H. \& Rohman, M. Extensive users of alcohol among college students. Journal of Studies on Alcohol, 1981, 42, 149-155.

Zax, M. \& Specter, G. An Introduction to Community Psychology. New York: John Wiley, 1974. 